\title{
HUBUNGAN PATRON-KLIEN PADA USAHA BUDIDAYA UDANG WINDU (Penaeus monodon) DAN BANDENG (Chanos chanos) DI KABUPATEN INDRAMAYU, JAWA BARAT
}

\author{
Ellen Suryanegara dan Hikmah \\ Balai Besar Penelitian Sosial Ekonomi Kelautan dan Perikanan \\ JI. KS. Tubun Petamburan VI Jakarta 10260 \\ Telp. (021) 53650162, Fax. (021)53650159 \\ e-mail: ellen.surya@gmail.com \\ Diterima 25 Oktober 2012- Disetujui 27 November 2012
}

\begin{abstract}
ABSTRAK
Tujuan penulisan adalah untuk menggambarkan dinamika hubungan patron-klien pada pelaku usaha perikanan budidaya, khususnya antara bakul (pengumpul) dengan langgan (pembudidaya polikultur udang dan bandeng) di Kabupaten Indramayu. Metode penelitian dilakukan melalui pendekatan kualitatif. Analisis data dilakukan dengan pendekatan teori patron-klien dari James Scott (1972). Penelitian dilakukan pada tahun 2012 dengan jenis data yang dikumpulkan adalah data sekunder dan primer. Pengumpulan data sekunder dilakukan dengan cara mencatat dan mempelajari dokumen tertulis dan laporan-laporan, sedangkan data primer diperoleh melalui observasi dan wawancara mendalam dengan para pelaku usaha perikanan budidaya polikultur udang-bandeng yang terlibat dalam pola hubungan patron-klien. Hasil penelitian menunjukkan dalam hubungan patron klien, pengumpul bertindak sebagai pihak patron yang memilki modal (capital), kekuasaan (power), status, wewenang dan pengaruh terhadap pembudidaya (langgan). Pembudidaya merupakan subordinat, diposisikan sebagai klien, yakni sebagai bawahan dari si patron. Hubungan patron-klien ini bersifat dominatif dan sengaja dipelihara patron (pengumpul) agar klien (pembudidaya) menjadi tergantung dan terus menyediakan pasokan hasil budidayanya.
\end{abstract}

Kata kunci: patron-klien, budidaya, Indramayu

Abstract : Patron-Client Relationship of Shrimp and Milkfish Polyculture Business: Case Study in Indramayu District, West Java. By: Ellen Suryanegara and Hikmah

The purpose of study is to describe the dynamics of the patron-client relations in main actor of aquaculture bussiness, especially beetwen bakul (collector/middlemen) with langgan (farmers) of shrimp and milkfish polyculture in Indramayu district. The research method is done through qualitative approach. Data analysis was done with the theory of the patron-client approach of James Scott (1972). Research conducted in 2012 with the type of data collected is secondary and primary data. Secondary data collection is done by recording and studying written documents and reports, while the primary data obtained through observation and in-depth interview with people in shrimp and milkfish polyculture business that engaged in a pattern of patron-client relationships. The results of the study found that the collector acts as the patron who has the capital, power, status, authority and influence on farmers (langgan). Farmers positioned as the client, as a subordinate of the patrons. This patron-client relationship is a dominative relation and deliberately maintained by patron (collector) to clients (farmers), so that the farmers became dependent and keep continue to supply the aquaculture product.

Keywords : patron-client, aquaculture, Indramayu

\section{PENDAHULUAN}

Sejarah masyarakat Indonesia di Pulau Jawa, secara sosial-budaya, ekonomi dan politik kerap kali menunjukan praktik feodalisme, tercatat sejak masa kerajaan atau prakolonialisasi hingga masa Orde Baru. Praktek tersebut berlangsung secara terus-menerus, dan kemudian direproduksi oleh struktur organisasi yang lebih formal pada masa sekarang. Lebih lanjut, struktur masyarakat feodal tersebut menciptakan kesenjangan dalam kehidupan sosial maupun ekonomi, memunculkan suatu pola hubungan patron-klien atau yang biasa dikenal dengan 'patronase' (patronage). Relasi patronklien ini telah mendarah daging dan bertransformasi dalam berbagai bentuk dengan berbagai variasi dan subordinasi patron terhadap klien.
Hegemoni patron menjadi kunci penting dalam bertahannya pola hubungan patron-klien. Pihak patron yang semakin merajarela terus menambah kapital (kekayaan), dengan modal dan jaringan yang ia miliki, kerja keras para klien ia nikmati dengan peningkatan kekayaan secara eksponensial. Di sisi lain, para klien semakin terjebak atau bahkan nyaman dengan berbagai jaminan yang diberikan patron, sehingga keadaan relasi tersebut membuat ia tidak bisa meningkatkan kesejahteraannya secara signifikan. Klien, seringkali terpaksa, dengan sadar menyerahkan hasil panen budidayanya kepada patron. Pola pikir menolak terhadap permintaan patron akan membuat situasi klien menjadi cenderung tidak aman. Namun, dalam kondisi yang stabil, hubungan kekuatan antara patron dan klien menjadi suatu norma yang mempunyai kekuatan moral 
sendiri dimana didalamnya berisi hak-hak dan kewajiban yang harus dilaksanakan oleh kedua belah pihak. Normanorma tersebut akan dipertahankan sejauh memberikan jaminan perlindungan dan keamanan dasar bagi klien (Anonim, 2011).

Pola hubungan patron-klien tersebut juga terkondisikan dalam sistem masyarakat perikanan budidaya di Indonesia pada saat ini, termasuk di Kabupaten Indramayu, Jawa Barat. Kabupaten Indramayu sebagai penghasil perikanan budidaya memiliki beberapa komoditas unggulan, yaitu udang windu (Penaeus monodon) dan bandeng (Chanos chanos) yang dibudidayakan secara polikultur. Pembudidaya polikultur udang windu-bandeng di Kabupaten Indramayu ini cenderung masih menggantungkan usahanya pada keberadaan pedagang pengumpul atau yang biasa disebut dengan bakul. Ketergantungan tersebut terwujud dalam suatu keterikatan hutang dimana pembudidaya diberikan modal usaha berupa benih maupun pakan dengan syarat harus mengembalikan hutang dan menyetorkan hasil panennya kepada pengumpul yang memberi modal. Walaupun bersifat timbal-balik seringkali dalam hubungan ini pembudidaya merasa dirugikan karena tidak bisa bebas dalam menentukan harga jual.

Uraian di atas menjadi landasan dalam penulisan makalah ini, yakni bertujuan untuk menggali hubungan patron-klien antara pedagang pengumpul dengan pembudidaya polikultur udang windu (Penaeus monodon) dan bandeng (Chanos chanos) di Kabupaten Indramayu, Jawa Barat. Penelitian ini merupakan penelitian kualitatif dengan menggunakan pendekatan studi kasus. Menurut Creswell (1997) dalam studi kasus, analisis terdiri dari membuat penjelasan (description) rinci tentang kasus (case) pada lokasi tertentu (setting), dalam hal ini studi kasus dilakukan di Kabupaten Indramayu, Jawa Barat dengan membatasi pada pelaku usaha perikanan budidaya polikultur udang dan bandeng yang ada di Kecamatan Pasekan. Penelitian dilakukan pada tahun 2012 dengan jenis data yang dikumpulkan adalah data sekunder dan primer. Pengumpulan data sekunder dilakukan dengan cara mencatat dan mempelajari dokumen tertulis dan laporan-laporan, sedangkan data primer diperoleh melalui observasi dan wawancara mendalam (in-depth interview) dengan para pelaku usaha perikanan budidaya polikultur udangbandeng yang terlibat dalam pola hubungan patronklien. Tulisan ini diharapkan dapat memberikan masukan untuk penelitian lanjutan, dan memberi masukan pada pengambil kebijakan sebagai langkah awal untuk menyusun strategi kebijakan tentang pemberdayaan masyarakat.

\section{GAMBARAN UMUM MASYARAKAT PEMBUDIDAYA IKAN}

Perikanan budidaya mencakup budidaya ikan di air tawar, payau dan budidaya laut di Kabupaten Indramayu saat ini sudah cukup berkembang, hal ini ditandai dengan aktifitas perikanan budidaya yang telah tersebar di 31 kecamatan yang ada di Kabupaten Indramayu. Jumlah seluruh pembudidaya ikan di Indramayu sebanyak 26.987 orang. Luas lahan yang diusahakan untuk budidaya perikanan mencapai 23.045,88 hektar. Total produksi ikan hasil budidaya mencapai 134.937,91 ton dengan nilai Rp. 2.072 milyar. Kegiatan pemasaran hasil perikanan dan kelautan dilakukan oleh pedagang ikan atau bakul ikan dengan jumlah 1.125 orang. Pusat penjualan ikan dilakukan di seluruh TPI (Tempat Penjualan Ikan) dan di Pasar Ikan Higienis yang terletak di Kecamatan Indramayu (Dinas Perikanan dan Kelautan Kabupaten Indramayu, 2011).

Komoditas unggulan yang dibudidayakan di Indramayu adalah ikan bandeng (Chanos chanos), udang windu (Penaeus monodon), udang vaname (Penaeus vannamei), lele (Clarias sp), nila (Oreochromis niloticus), gurame (Osphoronemus gouramy), mas (Cyprinus carpio), kerapu (Epinephelus pachycentru), dan rumput laut (Gracillaria $s p$ ). Disamping itu terdapat komoditas lain yang sifatnya bukan unggulan yaitu: belut, ikan hias dan kepiting dalam jumlah yang relatif sedikit. Beberapa kecamatan menjadi sentra produksi budidaya perikanan yaitu Kecamatan Losarang menjadi sentra budidaya ikan air tawar (ikan lele), Kecamatan Pasekan menjadi sentra budidaya ikan di tambak air payau (udang windu, udang vaname dan ikan bandeng). Dalam hal ini kecamatan lain merupakan kecamatan pendukung kegiatan budidaya ikan di Indramayu.

Kecamatan Pasekan dengan komoditas utama udang, ditetapkan sebagai kawasan pengembangan Minapolitan Budidaya di Kabupaten Indramayu pada tahun 2012. Teknologi budidaya yang banyak dikembangkan yaitu polikulttur udang dan bandeng. Dalam hal ini polikultur yang banyak di usahakan adalah budidaya bandeng (Chanos chanos) dan udang windu (Penaeus monodon) dalam satu tambak. Budidaya polikultur ini sangat menguntungkan pembudidaya dari segi ekonomis dan teknis. Dari segi ekonomis pembudidaya bisa panen dua komoditas sekaligus dalam satu siklus budidaya, sedangkan dari segi teknis pemeliharaan juga lebih mudah dan murah. Secara biologis persyaratan parameter kualitas air untuk kehidupan udang dengan bandeng sama. Keduanya tidak saling kanibal karena udang windu hidupnya didasar sedangkan bandeng di permukaan air (Atjo dan Yusuf, 2011).

Dari hasil penelitian menunjukan bahwa mayoritas penguasaan lahan tambak oleh pembudidaya merupakan milik sendiri dan sewa dengan jumlah kepemilikan lahan tambak adalah sekitar 2-5 hektar. Pembudidaya yang memiliki lahan milik sendiri biasanya merupakan pembudidaya yang telah menjalankan usahanya secara turun-temurun, sehingga kepemilikan lahan merupakan warisan dari generasi sebelumnya (orangtua). Biaya sewa lahan tambak, dari pemerintah 
setempat atau dari pemilik lahan berkisar 2,5-5 juta/ hektar/ tahun.

\section{ALUR PERTUKARAN EKONOMI USAHA BUDIDAYA}

Di Kabupaten Indramayu terdapat beberapa pengumpul udang dan bandeng yang tersebar di berbagai wilayah. Pengumpul ini menampung hasil panen pembudidaya dan selanjutnya memasok udang dan bandeng tersebut ke pasar lokal kabupaten dan luar kabupaten. Bandeng serta udang yang dijual terdiri dari berbagai ukuran (size) sesuai dengan permintaan pasar. Pada umumnya pengumpul ini sudah memiliki kelompok pembudidaya yang menjadi langgan (pemasok) udang windu dan bandeng. Suplai udang dan bandeng sangat dipengaruhi oleh hasil produksi tambak-tambak pembudidaya yang menjadi kliennya. Klien atau langgan ini adalah para pembudidaya yang diberi pinjaman modal dan harus menjual kembali hasil panennya kepada patron (pengumpul) tersebut.

Budidaya udang dan bandeng di Kabupaten Indramayu mayoritas masih dijalankan secara tradisional. Pembudidaya masih kurang responsif terhadap teknologi karena adanya keterbatasan permodalan. Keterbatasan modal inilah yang menyebabkan pembudidaya sering meminjam uang ke pengumpul (bakul). Bentuk pinjaman ini biasanya berupa benih, pakan maupun modal berupa uang. Permasalahan yang lain adalah kurang pengetahuannya tentang cara menangani penyakit, sehingga menyebabkan tingkat mortalitas dan potensi resiko gagal panen menjadi tinggi. Gagal panen mendorong pembudidaya (langgan) terpaksa meminjam (hutang) benih kembali ke pengumpul (bakul) tempatnya mendapatkan pinjaman modal.

Harga jual udang windu dan bandeng dari pembudidaya ke pengumpul seringkali juga ditentukan secara sepihak oleh pengumpul. Ikatan pinjaman modal membuat pembudidaya harus mengikuti harga yang berlaku dari pengumpul yang menjadi patronnya. Selain itu informasi pasar, baik informasi harga maupun pembeli, sangat terbatas dan dikuasai oleh pengumpul menyebabkan pembudidaya tidak mempunyai jalan lain selain menjual hasil panennya pengumpul yang memberi modal. Secara umum gambaran alir pertukaran ekonomi perikanan budidaya polikultur udang dan bandeng antara pembudidaya (langgan) dengan pengumpul (bakul) dapat dilihat pada Gambar 1.

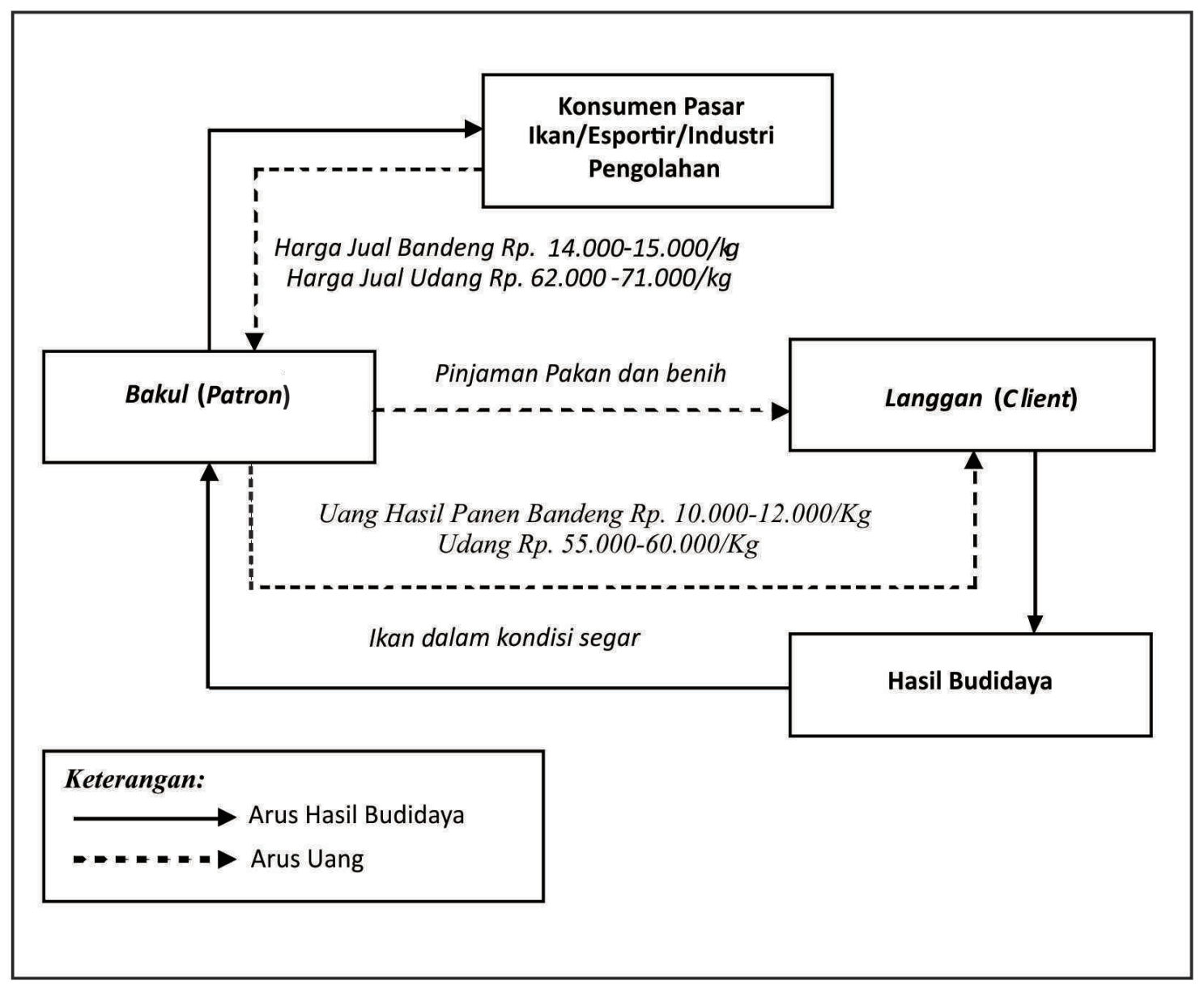

Gambar 1. Diagram Aliran Pertukaran Ekonomi pada Usaha Perikanan Budidaya Bandeng dan Udang di Kabupaten Indramayu.

Sumber: Data primer diolah, 2012 
Hasil budidaya yang telah dipanen oleh pembudidaya umumnya akan dihargai sebesar Rp. 10.000-12.000per kilogram untuk bandeng dan Rp. 55.000-60.000per kilogram untuk udang windu size 30 ekor $/ \mathrm{kg}$. Pembayaran hasil penjualan tersebut dilakukan secara tunai oleh pengumpul setelah jumlahnya dikurangi terlebih dahulu dengan jumlah hutang yang dimiliki pembudidaya. Pengumpul/ Bakul akan mengambil keuntungan rata-rata sebesar Rp.3.000-Rp.4.000 per kilogram bandeng dan Rp.7.000-Rp.11.000 per kilogram udang windu. Hasil budidaya kemudian dijual ke pasar ikan, eksportir dan industri pengolahan baik di tingkat kabupaten maupun luar kabupaten dalam kondisi segar (beku).

\section{HUBUNGAN PATRON-KLIEN}

Alur pertukaran ekonomi pada usaha perikanan budidaya tersebut menunjukan bahwa pengumpul bertindak sebagai pihak patron yang memilki modal (capital), kekuasaan (power), status, wewenang dan pengaruh terhadap pembudidaya (langgan). Pembudidaya disini sebagai pihak subordinat diposisikan sebagai klien, yang menjadi bawahan dari patron. Pola hubungan patron-klien ini merupakan aliansi dari dua kelompok komunitas atau individu yang tidak sederajat, baik dari segi status, wewenang, kekuasaan maupun penghasilan, sehingga klien ditempatkan dalam kedudukan yang lebih rendah dan patron dalam kedudukan yang lebih tinggi. Hal ini sesuai dengan pernyataan Lande (1964) dalam Rustiansyah (2011) yang menyebut model patron-klien sebagai solidaritas vertikal. Pola relasi yang ditemukan antara pembudidaya polikultur udang-bandeng dengan pengumpul (bakul) di Kabupaten Indramayu ini sesuai dengan ciri-ciri hubungan patron-klien yang sebagaimana diungkapkan oleh Scott (1972), diantaranya bahwa:

\section{Adanya ketidakseimbangan status antara patron dan klien dalam pertukaran (inequality of exchange).}

Ketidakseimbangan status tersebut adalah antara pengumpul (bakul) sebagai patron (superordinat) dan pembudidaya polikultur udang-bandeng (langgan) sebagai klien (subordinat). Adanya keterikatan hutang menyebabkan pembudidaya tidak dapat menjual hasil panennya ke pengumpul/pedagang yang lain dengan harga yang lebih tinggi, disini patron memiliki kebebasan untuk mengambil keputusan, menguasai informasi pasar dan menentukan harga secara sepihak. Terlihat bahwa disini terjadi sebuah bentuk eksploitasi dalam bentuk akumulasi modal, penekanan terhadap harga, monosponi (satu pembeli)-memaksakan pembudidaya (klien) menjual hasilnya ke bakul (patron). Biasanya bakul berani membayar di awal (ijon), sehingga pembudidaya tertarik untuk menjual kepada bakul.

\section{Meskipun patron mengharapkan bantuan dari klien, tetapi kedudukan patron lebih tinggi dibandingkan dari klien.}

Hal ini terlihat dari perilaku usaha pengumpul yang mengharapkan suplai hasil panen dari pembudidaya, namun di sisi lain kedudukan pengumpul tetap lebih tinggi dibandingkan dengan pembudidaya karena pengumpul merupakan pihak pemilik modal, pemegang informasi pasar serta pelaku yang bebas menentukan harga. Seorang bakul bisa memaksa langgan untuk menjual seluruh hasil budidaya kepadanya. Bakul juga berhak menetapkan harga, menentukan kualitas hasil budidaya, dan bahkan berhak menentukan untuk tidak meneruskan pemberian modal kepada langgan apabila langgan dianggap tidak patuh.

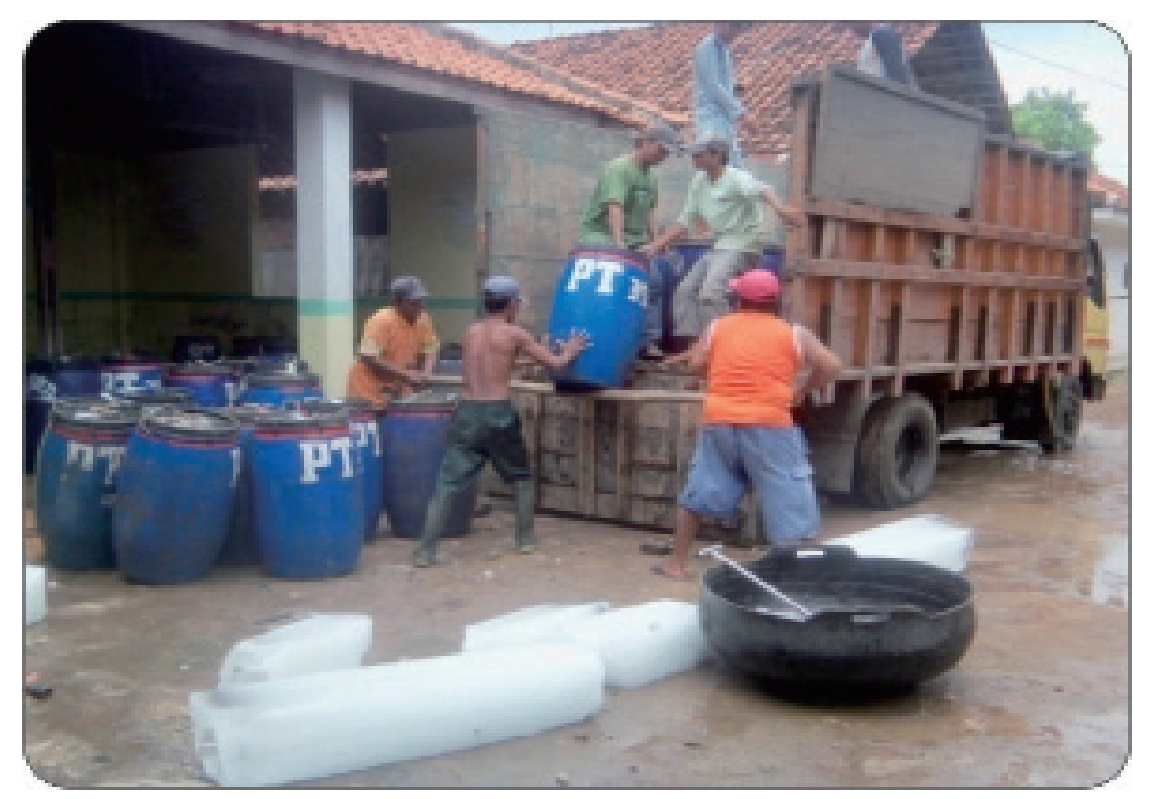

Gambar 2. Proses Pengangkutan Hasil Panen Pembudidaya Oleh Pengumpul 


\section{Keterikatan hutang antara klien pada patron menyebabkan adanya rasa utang budi kepada patron.}

Hal ini terlihat dari hubungan keterikatan pinjaman modal usaha baik berupa uang maupun barang yang dibutuhkan pembudidaya dari pengumpul yang menyebabkan adanya rasa utang budi dan ikatan moral bagi pembudidaya untuk menyetorkan panen pada pengumpul tersebut.

\section{Utang budi menyebabkan terjadinya ketergantungan.}

Hal ini terlihat dari adanya relasi timbal-balik yang menempatkan klien di bawah dominasi dan bayang-bayang "utang budi" dari pengumpul sebagai patronnya. Dengan begitu, klien tidak dapat lepas dari ketergantungan "kekuasaan" pengumpul. Tak jarang para pembudidaya sebagai klien semakin terjebak (atau bahkan nyaman) dalam keadaan relasi yang membuat ia tidak bisa meningkatkan kesejahteraannya secara signifikan. Keterikatan hutang ini menjadi sebuah siklus yang berlangsung secara terus-menerus bahkan sampai menurun ke generasi berikutnya.

Relasi patron klien ini terbentuk untuk mengatasi persoalan ketidakpastian memperoleh pendapatan. Pembudidaya polikultur udang-bandeng di Kabupaten Indramayu ini umumnya mencari patron untuk mendapatkan keamanan subsistensi sepanjang tahun. $\mathrm{Hal}$ ini mengingat kebutuhan hidup yang semakin meningkat, harga pakan, benih serta peralatan budidaya yang semakin mahal, sehingga tidak sebanding dengan yang didapatkan dari hasil budidaya. Persoalan pembudidaya ini kemudian dipandang sebagai peluang yang menguntungkan bagi kelompok tertentu yang memposisikan diri sebagai pemberi bantuan modal. Pedagang pengumpul (bakul) sebagai patron ingin mendapatkan keuntungan yang lebih besar sehingga memanfaatkan situasi itu dengan memposisikan sebagai orang yang memberikan perlindungan tersebut kepada para pembudidaya yang menjadi kliennya.

Menurut Scott (1972), hubungan patron-klien juga bersifat langsung/ tatap muka (face to face character), artinya bahwa pengumpul (bakul) sebagai patron mengenal secara pribadi pembudidaya yang menjadi kliennya karena mereka bertemu tatap muka, saling mengenal pribadinya, dan saling mempercayai satu sama lain. Hubungan ini lambat laun menjadi hubungan yang sifatnya struktural dan dominatif, serta diterima sebagai tradisi yang diwariskan secara turun temurun.

Walaupun bersifat dominatif, masing-masing pihak memiliki peran dan fungsi tersendiri. Dilihat dari pola relasinya, hubungan patron-klien antara pengumpul dengan pembudidaya disini bertujuan untuk mendapatkan keamanan subsistensi (pendapatan), mengakses pasar, mendapatkan pekerjaan, dan modal. Pengumpul (bakul) sebagai patron mengharapkan suplai hasil budidaya, dan keuntungan untuk mengembangkan kegiatan usaha ekonominya. Pada posisi ini pengumpul mempunyai peranan yang besar dalam menggerakkan kegiatan ekonomi khususnya dalam usaha perikanan budidaya di pedesaan karena memberikan jaminan modal, membuka kesempatan kerja di desa, dan mendistribusikan hasil budidaya baik secara lokal maupun di luar kabupaten. Fungsi patron, selain menjamin dasar subsistensi bagi para kliennya tetapi juga menyerap kerugian-kerugian yang ditimbulkan oleh permasalahan budidaya (gagal panen, dII). Di sisi lain pembudidaya sebagai klien juga berperan besar dalam keberlangsungan usaha patron, karena tanpa suplai hasil panen dari pembudidaya maka akan mengancam keberlanjutan usaha pengumpul yang bertindak sebagai patron.

Selain itu, munculnya pola patron-klien di masyarakat pembudidaya di Kabupaten Indramayu ini disebabkan belum adanya lembaga/institusi formal yang mampu berperan sebagaimana "patron" dalam menjamin kepentingan ekonomi mereka. Melihat bahwa lembaga dan institusi bentukan yang ada selama ini belum berhasil secara efektif karena adanya kesenjangan antara kultur lembaga yang dibangun secara formal dan sarat akan birokrasi yang berbelit, dengan kultur pembudidaya yang masih menekankan aspek kepercayaan, personalitas dan kepraktisan. Fasilitas kredit yang diberikan oleh perbankan/lembaga keuangan seringkali terbatas dan sulit dipenuhi persyaratannya oleh para pembudidaya karena mempersyaratkan adanya agunan. Pada sisi lain kelompok-kelompok pembudidaya yang telah terbentuk selama ini juga belum mampu memberikan manfaat secara signifikan, khususnya kemampuan dalam hal mengorganisasikan diri untuk kepentingan bersama sesama pelaku usaha seprofesi. Kelompok-kelompok pembudidaya yang terbentuk selama ini seringkali merupakan kelompok dadakan yang terbentuk atas dasar kepentingan untuk mendapatkan bantuan dari pemerintah.

\section{KESIMPULAN DAN SARAN}

Pola relasi yang tercermin dalam hubungan patron-klien antara bakul-langgan ini merupakan salah satu institusi jaminan sosial-ekonomi yang berkembang di masyarakat perikanan budidaya di Kabupaten Indramayu. Terlebih ketika akses terhadap pekerjaan dan permodalan dari pemerintah sulit dijangkau.

Mekanisme hubungan patron-klien ini seringkali bersifat dominatif dan sengaja dipelihara patron (pengumpul) agar klien (pembudidaya) menjadi tergantung dan terus menyuplai pasokan hasil budidayanya. Hubungan patron-klien ini dapat menggerakan kegiatan ekonomi perdesaan karena memberikan perlindungan subsistensi kepada pembudidaya yang kekurangan modal, menciptakan lapangan pekerjaan, mengakses pasar serta menjadi 
mediator untuk mendistribusikan hasil panen ke luar kabupaten.

Peran pemerintah disini menjadi penting dalam rangka mendukung kemandirian masyarakat pembudidaya agar tidak lagi bergantung pada patron. Pemerintah melalui kewenangannya harus mampu membatasi ruang gerak dominasi pihak para pelaku pasar sektor perikanan dengan menawarkan permodalan atas nama koperasi atau lembaga keuangan dengan pendekatan yang lebih personal dan sifatnya membantu permodalan pembudidaya dengan pinjaman berbunga rendah dan syarat yang tidak berbelit-belit.

\section{DAFTAR PUSTAKA}

Anonim. 2010. Patron Klien di Indonesia. (http:// www.pensa-sb.info/patron-klien-di-indonesia/, diakses pada tanggal 26 September 2012). . 2011. Masalah Hubungan Patron Klien di Desa Nangsri Karanganyar. (http://www.fisip.uns. ac.id/ diakses pada tanggal 26 September 2012).

Atjo, A. S., dan M. Yusuf. 2011. Artikel Penyuluhan Tahapan Polikultur Udang Windu. Diakses dari http://www.pusluh.kkp.go.id/ pada tanggal 25 September 2012.

Badan Perencanaan dan Pengembangan Daerah Kabupaten Indramayu. 2011. Rencana Pembangunan Jangka Menengah Daeah (RPJMD) Kabupaten Indramayu. Badan Perencanaan dan Pengembangan Daerah Kabupaten Indramayu. Indramayu.
Balai Besar Penelitian Sosial Ekonomi Kelautan dan Perikanan. 2012. Kajian Pengembangan Kawasan Minapolitan Perikanan Budidaya dan Pengembangan 7 Komoditas Budidaya. Balai Besar Penelitian Sosial Ekonomi Kelautan dan Perikanan. Jakarta.

Creswell, J. W. 1997. Qualitative Inquiry and Research Design Choosing Among Five Traditions. SAGE Publications, Inc. California

Dinas Perikanan dan Kelautan Kabupaten Indramayu. 2011. Laporan Akhir Kegiatan Penyusunan Master Plan Kawasan Minapolitan Kabupaten Indramayu. Dinas Perikanan dan Kelautan Kabupaten Indramayu. Indramayu.

Humaedi, M. A. 2010. Jeragan Nemen : Dinamika Hubungan Bakul-Langgan dalam Perspektif Politik Indonesia. Jurnal Masyarakat Indonesia XXXVI(2). Lembaga Ilmu Pengetahuan Indonesia. Jakarta.

Rustiansyah. 2011. Hubungan Patron Klien di Kalangan Pembudidaya Desa Kebonrejo. Universitas Airlangga. Surabaya.

Scott, J.C. 1972. The Erosion of Patron-Client Bonds and Social Change in Rural Southeast Asia. The Journal of Asian Studies. 32(1) November 1972. Association for Asian Studies Stable. 